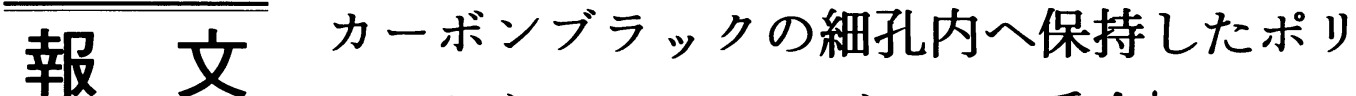 マーからのアニオングラフト重合
}

(平成 4 年 8 月 21 日 受理)

坪川 紀夫*.土田 秀世*・小林 清高*

\begin{abstract}
要 旨 多孔質のカーボンブラックであるポーラスブラックヘのポリェステルの表面グラフト化について 検討した。 まず，粒子表面へグラフト重合の開始基を導入する目的で，ポーラスブラックの細孔内へアクリ ル酸カリウムと重合開始剤とを水溶液中で吸着させた後, 重合を行った. その結果, ポーラスブラックの細 孔内へポリアクリル酸カリウム (PPA)が保持(PPAの保持率は，9.5\%)できることがわかった。次いで， PPAを保持したポーラスブラックを触媒に用いて，エポキシドと環状酸無水物とのアニオン開環交互共重 合を行ったところ，ポーラスブラックに保持されたPPAのカリウムカルボン酸塩基により, 重合が開始さ れ，粒子表面へ対応するポリエステルがグラフトすることが明らかとなった．例えば，スチレンオキシドと 無水フタル酸との共重合系では，グラフト率が17.7\%のものが得られた．更に，このような重合系へ18-ク ラウンー6を添加すると, グラフト率の大きなものが得られることもわかった.
\end{abstract}

\section{1. 緒言}

筆者らは, カーボンブラック表面を改質する目 的で, 粒子表面の様々な官能基を足場とする各種 ポリマーのグラフト反応について報告してき た 1 4). しかしながら，前報5〜10)でも指摘したよ らに, 表面官能基の少ないカーボンブラック表面 への高グラフト化は，特別の場合を除いて困難で あった.

そこで, 前報では, カーボンブラック表面の縮 合芳香族環のラジカル捕捉性, あるいは求電子置 換反応を利用する表面官能基の導入と，これらの 官能基を足場とするグラフト反応について報告し た

一方, 筆者らはカーボンブラック表面へ導入し たグラフト鎖からのグラフト重合 (2 次グラフト) を行らと, 非常に高グラフト率のポリマーグラフ トカーボンブラックが得られることを見い出し た 10 13). 例党ば, アクリル酸カリウムをグラフ ト（1 次グラフト）したカーボンブラックにより，

†本報を「官能基の少ないカーボンブラックへのグ ラフト反応(第 7 報)」とする.

* 新潟大学工学部化学システム工学科( 潟市五十嵐二の町8050)
エポキシドと環状酸無水物とのアニオン開環交互 共重合が開始され，粒子表面へ対応するポリエス テルが 2 次グラフトすることを報告した ${ }^{11)}$.

本研究では, 官能基の少ないポーラスブラック の細孔内へ保持(吸着)させたポリアクリル酸カリ ウムからのエポキシドと環状酸無水物とのアニオ ン開環交互共重合(式(1))を追跡し，ポーラスブラ ックヘのポリェステルのグラフト反応について検 討した.

PB

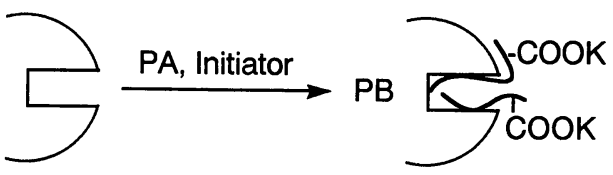

Porousblack

PPA retained PB : 1<smiles>[R]C1O[13CH][13C](=[18O])O1</smiles>

PB

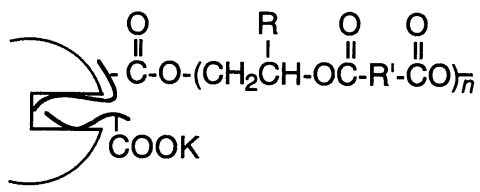


Table 1 Properties of carbon black used

\begin{tabular}{cccccc}
\hline Carbon black & BET surface area & $\begin{array}{c}\text { Particle size } \\
\left(\mathrm{m}^{2} / \mathrm{g}\right)\end{array}$ & $\begin{array}{c}\mathrm{OH} \\
(\mathrm{mmol} / \mathrm{g})\end{array}$ & $\begin{array}{c}\mathrm{COOH} \\
(\mathrm{mmol} / \mathrm{g})\end{array}$ & $\begin{array}{c}\mathrm{C}=\mathrm{O} \\
(\mathrm{mmol} / \mathrm{g})\end{array}$ \\
\hline Asahi $60 \mathrm{H}$ & 60 & 41 & 0.004 & 0 & 0.023 \\
Porousblack & 447 & 41 & 0.030 & 0 & 0.430 \\
\hline
\end{tabular}

\section{2. 実 験 方 法}

\section{1 ポーラスブラック}

ポーラスブラックは, 旭カーボン侏より提供を 受けたものを使用した。これはフファーネスブラ ックの旭60Hを水蒸気により賦活処理したもの であり，その性状を Table 1 に示した．粒子表面 のカルボキシル基, フェノール性水酸基, 及びキ ノン型酸素の量は，それぞれ，炭酸ナトリウム 法14)，1,1-ジフェニルー2-ピクリルヒドラジル 法15), 及び水素化ホウ素ナトリウム法 ${ }^{16)}$ により求 めた。 ポーラスブラックは, 使用前に $110^{\circ} \mathrm{C} て ゙$ 真 空乾燥させた。

\section{2 試薬}

アクリル酸カリウム $(\mathrm{PA})$ は, 浅田化学工業(侏) から提供を受けたものをそのまま使用した。スチ レンオキシド(SO)及びェピクロルヒドリン $(\mathrm{ECH})$ は, 水素化カルシウム上で脱水したもの を，蒸留により精製した。無水フタル酸(PAn), 無水マレイン酸(MAn), 及び無水コハク酸 (SAn)は，再結晶した後，減圧下で昇華して精製 した.

4,4'-アゾビス(4-シアノプロパノール) (ACPr), 及び2,2'-アゾビス [2-メチル-N-(2-ヒドロキシ) プロピオンアミド] (AMHP)は, 和光純薬工業 侏)から提供を受けたものをメタノールから再結晶 して使用した。

18-クラウン-6(CE)及び $N$-フェニルー $\beta$-ナフチ ルアミン（NPNA）は，東京化成(侏)ののを精製す ることなく，真空乾燥させてから使用した。

\section{3 ポーラスブラックの細孔内へのポリアク}

\section{リル酸カリウムの保持}

$100 \mathrm{ml}$ のナス型フラスコにPAを $0.5 \mathrm{~g}$ と $\mathrm{ACPr}$ あるいは AMHPを $0.5 \mathrm{mmol}$ 加え，これらを $10.0 \mathrm{ml}$ の純水に溶解させた後, ポーラスブラッ クを $0.5 \mathrm{~g}$ 加えて, 室温で24時間かき混ぜた. 次 いで，反応液を $80^{\circ} \mathrm{C} に$ 加熱して，重合を開始さ せた，反応後，生成物をメタノール中へ投入し，
ポーラスブラックとポリアクリル酸カリウム （PPA）とを沈殿させた．PAの重合率は式(2)から 求めた.

$$
\begin{aligned}
& \text { 重合率 }(\%)=\frac{A}{B} \times 100 \\
& A: \text { 生成物 }(\mathrm{g}) \text {-ポーラスブラック }(\mathrm{g}) \\
& B: \text { 仕込みモノマー }(\mathrm{g})
\end{aligned}
$$

次いで，重合生成物を水を溶媒に用いてソック スレー抽出を行い, ポーラスブラックの細孔内に 保持されなかった PPAを完全に取り除いた。ポ ーラスブラックの PPA 保持率は, 式(3)から求め た。

$$
\begin{gathered}
\mathrm{PPA} \text { 保持率 }(\%)=\frac{A}{B} \times 100 \\
A: \text { 保持された PPA }(\mathrm{g}) \\
B: \text { ポーラスブラック }(\mathrm{g})
\end{gathered}
$$

\subsection{PPA を保持したポーラスブラックによる} エポキシドと環状酸無水物とのアニオン 開環交互共重合

$100 \mathrm{ml}$ のナス型フラスコに, PPA を保持した ポーラスブラックを $0.20 \mathrm{~g}$ ，エポキシドを0.01 $\mathrm{mol}$, 及び環状酸無水物を $0.01 \mathrm{~mol}$ 加之, 乾燥窒 素雾囲気下，マグネチックスターラーでかき混ぜ

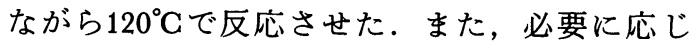
て, 重合系へアニオン重合促進剤の CE とラジカ

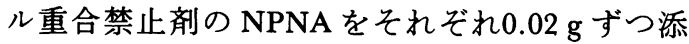
加した。

反応後, 生成物を多量のメタノール中へ投入し て，ポーラスブラックとポリマーとを沈殿させ た. 重合率は, 式(2)から求めた.

\section{5 グラフト率}

生成物をテトラヒドロフランを溶媒に用いてン ックスレー抽出を行い, 非グラフトポリマーを完 全に除去し，ポリマーがグラフトしたポーラスブ ラックを単離した。グラフト率は, 式(4)から求め た.

$$
\text { グラフト率 }(\%)=\frac{A}{B} \times 100
$$


$A:$ グラフトしたポリェステル $(\mathrm{g})$

$B:$ ポーラスブラック $(\mathrm{g})$

なお,グラフトしたポリェステルの質量は, 反 応後のポーラスブラックの質量増加から求めた。

\section{3. 結果と考察}

\section{1 ポーラスブラックの細孔内への PPA の} 保持

Table 1 からわかるように，゚ーラスブラック は，賦活前と比べ平均粒子径が変化しないにもか かわらず，賦活処理により比表面積が非常に大き くなることから，多くの細孔を含んでいるものと 考えられる.

したがって，ポーラスブラック表面へグラフト 重合の開始基(カリウムカルボン酸塩基)を導入す る目的で，細孔内への PPA の保持について検討 した.すなわち，重合開始剂を溶解したビニルモ ノマーをポーラスブラックの細孔内へ吸着させた 後, 重合反応を行らと, 生成するポリマーが細孔 内へ保持 (吸着)されるるのと予想される.

そこで，ポーラスブラックの細孔内へPA と ACPr とを水溶液中で吸着させて, 重合を行った とさの重合時間と重合率及び PPA の保持率との 関係を Fig. 1 に示した。 ポーラスブラックへの PPA の保持率は, 重合率の増加とともに增加し, 24時間後には, $9.7 \%$ に達した.

一方, 賦活処理前の旭 $60 \mathrm{H}$ について同様の重

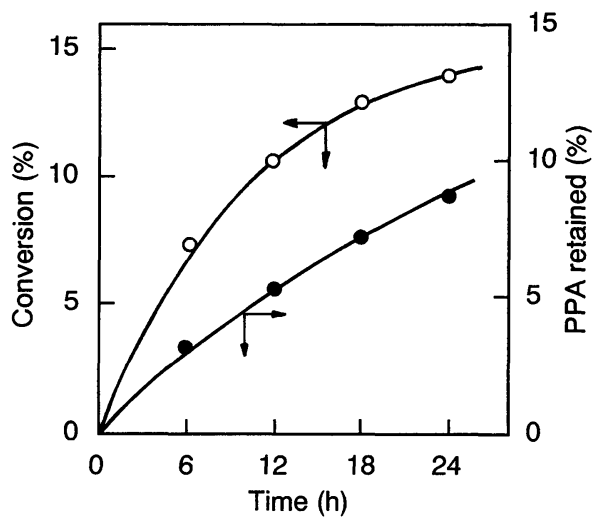

Fig. 1 PPA retained on Porousblack by the polymerization of PA initiated by ACPr. Porousblack, $0.50 \mathrm{~g}$; PA, $0.50 \mathrm{~g}$; ACPr, $0.5 \mathrm{mmol}$; $\mathrm{H}_{2} \mathrm{O}, 10.0 \mathrm{ml} ; 80^{\circ} \mathrm{C}$.
合を行ったが，ソックスレー抽出後，粒子表面に 残存する PPA の量(保持量)は, $3.1 \%$ に過ぎなか った.

更に, PPAを保持したポーラスブラックの比 表面積は, $250 \mathrm{~m}^{2} / \mathrm{g}$ に減少していることもわか った.

以上の結果から，ポーラスブラックの細孔内へ の重合開始剂を溶解したモノマーを吸着させた 後, 重合を行らことにより, 細孔内へポリマーを 保持できることが明らかとなった。

Table 2 には, ポーラスブラックの細孔内への PPA 保持率に及ぼす重合開始剤の影響を調べた 結果を示した。重合開始剤として ACPr の代わり に, AMHPを用いると, PA の重合率及び PPA の保持率が若干低下寸ることがわかった，これは， $\mathrm{ACPr}$ と AMHP との分解の半減期が異なること によるものと考えられる.

3.2 PPA を保持したポーラスブラックによる SO とPAn とのアニオン開環交互共重合

カルボン酸のアルカリ金属塩により, エポキシ ドと環状酸無水物とのアニオン開環交互共重合が 開始され，ポリェステルが生成することは良く知 られている17)。また，我々は，カルボン酸のカリ ウム塩基を導入したカーボンブラック18)やシリ カ19)などを用いると，粒子表面でエポキシドと環 状酸無水物とのアニオン開環交互共重合が開始さ れ，粒子表面へ対応するポリエステルが効率よく

Table 2 Effect of initiator on the retention of PPA in pores of Porousblack ${ }^{\mathbf{a}}$

\begin{tabular}{ccc}
\hline Initiator & Conversion(\%) & PPA retained (\%) \\
\hline ACPr & 13.8 & 9.7 \\
AMHP & 12.3 & 8.8 \\
\hline
\end{tabular}

a) Porousblack, $0.50 \mathrm{~g} ; \mathrm{PA}, 0.50 \mathrm{~g}$; initiator, 0.5 $\mathrm{mmol} ; \mathrm{H}_{2} \mathrm{O}, 10 \mathrm{ml} ; 80^{\circ} \mathrm{C} ; 24 \mathrm{~h}$.

Table 3 Anionic ring-opening copolymerization of SO with PAn Initiated by PPA-retained Porousblack ${ }^{\text {a) }}$

\begin{tabular}{lcc}
\hline Porousblack & Conversion(\%) & Grafting(\%) \\
\hline None & 0 & - \\
Untreated & 0 & 0 \\
PPA-retained & 39.6 & 17.7 \\
\hline
\end{tabular}

a) Porousblack, $0.20 \mathrm{~g}$; $\mathrm{SO}=\mathrm{PAn}=0.01 \mathrm{~mol} ; 120^{\circ} \mathrm{C}$; $2 \mathrm{~h}$. 
グラフトすることを報告した.

そこで, 本研究では, ポーラスブラックの細孔 内に保持された PPA のペンダントのカリウムカ ルボン酸塩基を触媒に用いる, SO と PAn との アニオン開環交互共重合について検討した.

Table 3 には, PPAを保持したポーラスブラッ クの存在下でSO とPAnとのアニオン開環交互 共重合を $120^{\circ} \mathrm{C} て ゙$ 行ったときの結果を示した。モ ノマー単独の系や未処理のポーラスブラックの系 では, 重合は全く進行しなかった。 これに対して, PPAを保持したポーラスブラックの存在下では, SO とPAn とのアニオン開環交互共重合が開始 され，しかも粒子表面へ対応するポリエステルが

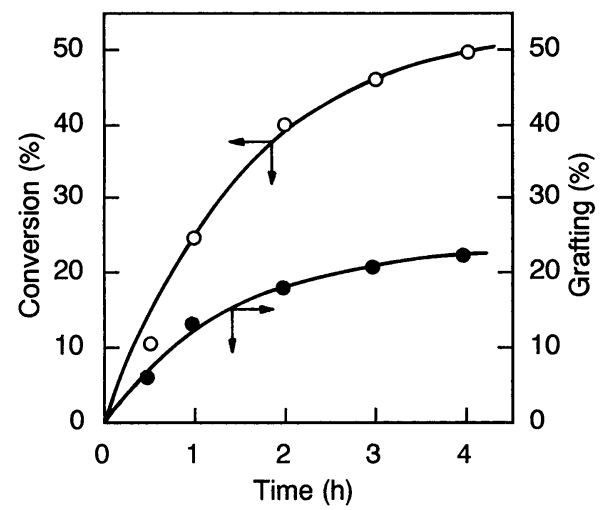

Fig. 2 Anionic ring-opening copolymerization of SO with PAn initiated by PPA-retained Porousblack. Porousblack, $0.20 \mathrm{~g}$; SO $=\mathrm{PAn}=0.01 \mathrm{~mol} ; 120^{\circ} \mathrm{C}$.

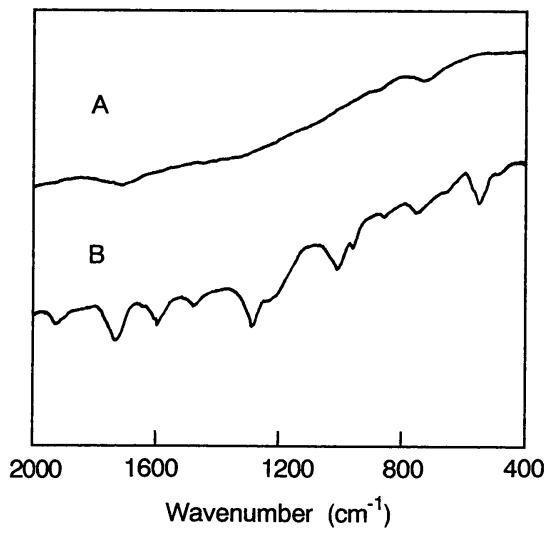

Fig. 3 Infrared spectra ( $\mathrm{KBr}$ ) of (A) untreated and (B) polyester-grafted Porousblack.
グラフトすることがわかった.

Fig. 2 には, SO とPAn との共重合を行ったと きの重合時間と重合率及びグラフト率との関係を 示した. 重合時間と共に重合率, グラフト率共に 増大し,グラフト率は，4 時間後20\%に達した。

Fig. 3 には，このような重合系で得られたポー ラスブラックの IR スペクトルを未処理のものと 比較して示した。重合系で得られたポーラスブラ ックのIR スペクトルには, SO と PAn との共重 合体(ポリエステル)の特性吸収が認められ，これ からも粒子表面へのポリエステルのグラフトが明 らかである。

Fig. 4 には，未処理のポーラスブラック， PPA を保持したポーラスブラック，及びポリェ ステルをグラフトしたポーラスブラックの熱重量 曲線を示した，PPAを保持あるいはポリエステ ルをグラフトしたポーラスブラックの場合は, $200^{\circ} \mathrm{C}$ 付近から, PPA 及びポリェステルの熱分解 に基づく質量減少が認められた.

以上のような結果は，ポーラスブラックに保持 された PPAのカリウムカルボン酸塩基からグラ フト鎖の生長が起こっていることを示唆している.

3.3 各種エポキシドと環状酸無水物とのアニ オン開環交互共重合

Table 4 には，PPAを保持したポーラスブラッ クを触媒に用いて，各種のエポキシドと環状酸無 水物とのアニオン開環交互共重合を行ったときの 結果を示した。ここでは，エポキシドとして，

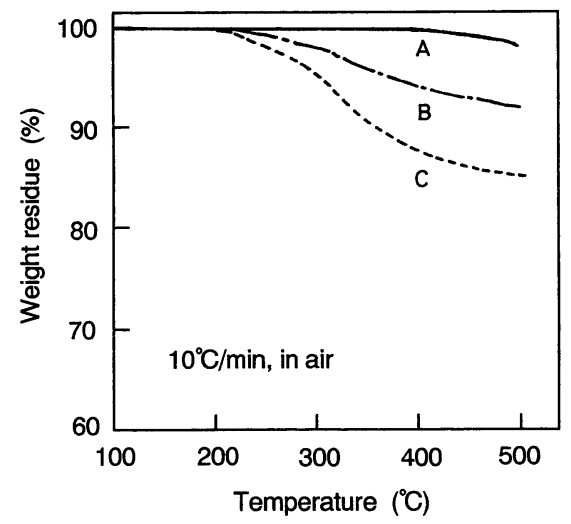

Fig. 4 Thermogravimetric curves of (A) untreated, (B) PPA-retained-, and (C) polyester (SO and PAn)-grafted porousblack. 
Table 4 Anionic ring-opening copolymerization of epoxides with cyclic acid anhydrides initiated by PPA-retained Porousblack ${ }^{a}$ )

\begin{tabular}{cccc}
\hline Epoxide & Anhydride & Conversion(\%) & Grafting(\%) \\
\hline SO & PAn & 39.6 & 17.7 \\
SO & MAn & 20.3 & 23.4 \\
SO & SAn & 11.5 & 18.7 \\
ECH & PAn & 11.8 & 21.8 \\
ECH & MAn & 5.6 & 18.3 \\
ECH & SAn & 2.6 & 8.8 \\
\hline
\end{tabular}

a) Porousblack, $0.20 \mathrm{~g}$; epoxide $=$ anhydride $=0.01$ $\mathrm{mol} ; 120^{\circ} \mathrm{C} ; 2 \mathrm{~h}$.

$\mathrm{SO}$ と $\mathrm{ECH}$ を, 環状酸無水物として, PAn, MAn，及びSAnを使用した。 これからいずれの 系でも，アニオン開環交互共重合が開始され，粒 子表面へ対応するポリエステル（IR 及び NMR で 確認)がグラフトすることがわかった.

したがって，このようなグラフト重合によれ ば，表面官能基の少ないポーラスブラック表面へ も様々な機能を持つポリエステルをグラフトでき ることになる。

\section{4 グラフト重合に及ぼす CE の添加効果}

アニオン重合系へ GE を添加すると重合速度が 著しく大きくなることは良く知られている20). 筆 者らは, カリウムカルボン酸塩基を導入したカー ボンブラックを用いるエポキシドと環状酸無水物 とのアニオン開環交互共重合系へ CE を添加する と，重合速度が増大すると共にグラフト率の大き なものが得られることを報告した ${ }^{21)}$.

そこで，PPAを保持したポーラスブラックに よるエポキシドと環状酸無水物とのアニオン共重 合系への CE の添加効果について調べた結果を Fig. 5 に示した。これから, 本重合系においても CE の添加により，グラフト率の大きなものが得 られることが明らかとなった。

\section{4. 総括}

（1）ポーラスブラックの細孔内へ PA と重合開 始剂とを水溶液中で吸着させた後，重合を開始 させることにより，細孔内へPPAが保持でき ることがわかった。

(2) PPAを保持したポーラスブラックにより， エポキシドと環状酸無水物とのアニオン開環交 互共重合が開始され，粒子表面へ様々な構造を

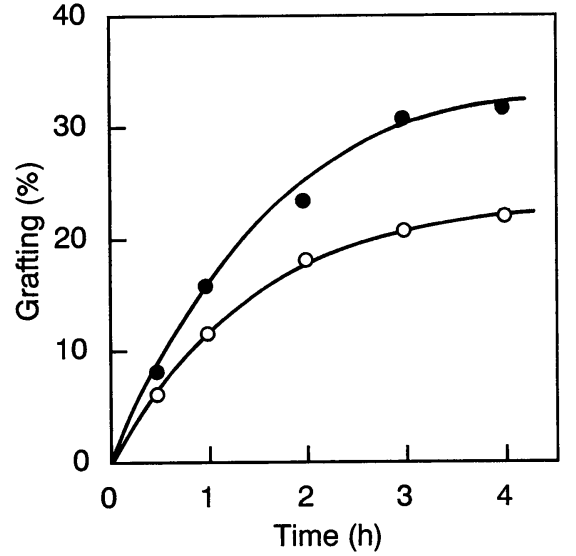

Fig. 5 Effect of crown ether on the anionic ring-opening copolymerization of SO with PAn initiated by PPA-retained Porousblack. $(\bigcirc)$, in the absence of crown ether; (O), in the presence of crown ether.

持つポリエステルがグラフトすることが明らか となった。

\section{引用 文 献}

1）坪川紀夫, 遠藤 剛 : 炭素, No. 140, 322 (1989)

2）材料技術研究協会編，久保輝一郎他監修：導電性 材料をめぐる最近の動向，材料技術研究会（1992）, p. 85

3）坪川紀夫：色材, 65, 72 (1992)

4) Tsubokawa, N.: Prog. Polym. Sci., 17, 417 (1992)

5）坪川紀夫, 真柄和朗, 曽根康夫：日ゴム協誌, 62, 668 (1989)

6）坪川紀夫, 梁取和人, 曽根康夫：日ゴム協誌, 63, 268 (1990)

7）坪川紀夫, 梁取和人, 曽根康夫：日ゴム協誌, 63, 566 (1990)

8）坪川紀夫, 梁取和人, 曽根康夫：日ゴム協誌, 64, 267 (1991)

9）藤木一浩, 真柄和朗, 坪川紀夫, 曾根康夫 : 日ゴ 么協誌, 64, 378 (1991)

10）坪川紀夫，梁取和人：高分子論文集， 49, 865 (1992)

11）藤木一浩, 佐々木亨, 坪川紀夫：日本化学会第 59 春季年会講演予稿集 II, 1030 (1990)

12）坪川紀夫, 土田秀世, 小林清高 : Polym. Prepr., Jpn., 40, 1686 (1991)

13）土田秀世, 坪川紀夫：Polym. Prepr., Jpn., 41, 394 (1992)

14) Rivin, D.: Rubber Chem. Technol., 36, 729 (1963)

15) Ohkita, K. and Tsubokawa, N.: Carbon, 10, 631 (1972) 
16）鈴木祝寿, 宮崎国弘：日化誌，88，299（1967）

17) Schwenk, E., Gilubis, K., Roton, M., Benzing, G., Maysenholder, R. and Hamann, K.: Makromol. Chem., 51, 53 (1962)

18) Tsubokawa, N., Funaki, A., Hada, Y. and Sone, Y.: J. Polym. Sci., Polym. Chem. Ed., 20, 3297 (1982)
19) Tsubokawa, N., Kogure, A. and Sone, Y.: J. Polym. Sci., Part A: Polym. Chem., 28, 1923 (1990)

20）小田良平, 庄野利之, 田伏岩夫共編 : クラウンエ ーテルの化学, 化学同人 (1978), P. 77

21）坪川紀夫, 山田昭洋, 曽根康夫 : 高分子論文集, 42, 509 (1985)

\title{
GRAFTING ONTO CARBON BLACK HAVING FEW FUNC- TIONAL GROUPS 7. ANIONIC GRAFT POLYMERIZATION FROM POROUS CARBON BLACK INITIATED BY POLY (POTASSIUM ACRYLATE) RETAINED IN THE PORES
}

\author{
Norio TSUBOKAWA, Hideyo TSUCHIDA, and Kiyotaka KOBAYASHI (Faculty of \\ Engineering, Niigata University, 8050, Ikarashi 2-nocho, Niigata, 950-21, Japan)
}

The anionic graft polymerization from porous carbon black, i.e., Porousblack, initiated by pendant potassium carboxylate groups of poly (potassium acrylate) (PPA) retained in the pores was investigated. The retention (adsorption) of PPA in pores of the porous carbon black was achieved by the adsorption of potassium acrylate and 4,4'-azobis (4cyanopropanol) as initiator in water at room temperature followed by the polymerization by heating at $80^{\circ} \mathrm{C}$. After the polymerization, the carbon black was purified by Soxhlet extraction with water: the percentage of PPA retention in the pores was estimated to be $9.7 \%$. By the retention of PPA, the specific surface area of the carbon black was decreased from 477 $\mathrm{m}^{2} / \mathrm{g}$ to $250 \mathrm{~m}^{2} / \mathrm{g}$. These results indicate the retention of PPA in pores of the carbon black. It was found that the anionic ring-opening alternating copolymerizations of epoxides with acid anhydrides are initiated by the PPA-retained carbon black to give the corresponding polyester-grafted carbon black. For instance, the percentage of grafting of polyester from styrene oxide and phthalic anhydride was $17.7 \%$. Based on the results, it is concluded that pendant potassium carboxylate groups of PPA retained in the pores of carbon black have an ability to initiate the anionic ring-opening copolymerization of epoxides with cyclic acid anhydrides and polyester is grafted onto the carbon black based on the propagation from the surface. The rate of polymerization and percentage of grafting was increased by the addition of 18-crown-6.

(Received on August 21, 1992) 